\title{
Article
}

\section{Law, Politics, and the Quality of Government in Africa}

Asongu, Simplice A. and Nwachukwu, Jacinta Chikaodi

Available at http://clok.uclan.ac.uk/24918/

Asongu, Simplice A. and Nwachukwu, Jacinta Chikaodi ORCID: 0000-00032987-9242 (2016) Law, Politics, and the Quality of Government in Africa. Politics \& Policy, 44 (5). pp. 916-944. ISSN 1555-5623

It is advisable to refer to the publisher's version if you intend to cite from the work. http://dx.doi.org/10.1111/polp.12171

For more information about UCLan's research in this area go to http://www.uclan.ac.uk/researchgroups/ and search for < name of research Group>.

For information about Research generally at UCLan please go to http://www.uclan.ac.uk/research/

All outputs in CLoK are protected by Intellectual Property Rights law, including Copyright law. Copyright, IPR and Moral Rights for the works on this site are retained by the individual authors and/or other copyright owners. Terms and conditions for use of this material are defined in the policies page.

\section{CLoK}

Central Lancashire online Knowledge www.clok.uclan.ac.uk

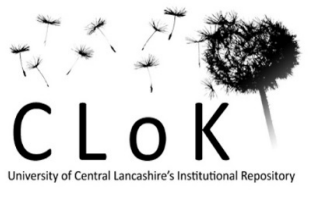




\section{MPRA \\ Munich Personal RePEc Archive}

\section{Law, Politics and the Quality of Government in Africa}

Simplice Asongu and Jacinta Nwachukwu

January 2016

Online at https://mpra.ub.uni-muenchen.de/74231/

MPRA Paper No. 74231, posted 3 October 2016 02:41 UTC 


\title{
$\underline{\text { A G D I Working Paper }}$
}

\section{WP/16/019}

\section{Law, Politics and the Quality of Government in Africa}

\author{
Forthcoming: Politics \& Policy
}

\author{
Simplice A. Asongu \\ African Governance and Development Institute, \\ P.O. Box 8413 Yaoundé, Cameroon. \\ E-mail: asongusimplice@yahoo.com /asongus@ afridev.org

\section{Jacinta C. Nwachukwu} \\ School of Economics, Finance and Accounting, \\ Faculty of Business and Law, \\ Coventry University \\ Priory Street, Coventry, CV1 5FB, UK \\ Email: jacinta.nwachukwu@ coventry.ac.uk
}




\title{
AGDI Working Paper
}

Research Department

\section{Law, Politics and the Quality of Government in Africa}

\author{
Simplice A. Asongu \& Jacinta C. Nwachukwu
}

January 2016

\begin{abstract}
This paper examines interconnections between law, politics and the quality of government in Africa. We investigate whether African democracies enjoy relatively better government quality compared to their counterparts with more autocratic inclinations. The empirical evidence is based on Instrumental variable Two-Stage-Least Squares and Fixed Effects with data from 38 African countries for the period 1994-2010. Political regimes of democracy, polity and autocracy are instrumented with income-levels, legal-origins, religious-dominations and press-freedom to account for government quality dynamics, of corruption-control, government-effectiveness, voice and accountability, political-stability, regulation quality and the rule of law. Findings show that democracy has an edge over autocracy while the latter and polity overlap. As a policy implication, democracy once initiated should be accelerated to edge the appeals of authoritarian regimes.

JEL Classification: K00; O10; P16; P43; P50

Keywords: Law; Politics; Democracy; Government Policy; Development
\end{abstract}




\section{Introduction}

A key issue in political economics is to understand how institutional arrangements shape policy outcomes. The effectiveness of development policies in Africa over the past decades has been contingent on the quality of government, notably: political governance (political stability and voice \& accountability), economic governance (government effectiveness and regulation quality) and institutional governance (corruption-control and rule of law) (Fosu 2013; Asongu and Nwachukwu 2015). There is some consensus on the positive relationship between the promotion of democracy and outcomes in policies and institutions that are favourable to government quality (Fosu 2008; Kim 2014). Moreover some scholars believe that democracies have important effect on the degree of competition for public offices but otherwise have insignificant influence on good governance (Mulligan et al. 2004). Conversely, there is a stream of literature maintaining that autocracies are still much better in governance compared to 'early democracies' (Moyo 2013).

The debate has been reignited in contemporary political literature with the emergence of China as an economic super power in spite of her system of government that is not consistent with Western-style liberal democracy (Asongu and Ssozi 2016). This has led to a new stream of literature on the reconciliation of the Washington Consensus (WC) with the Beijing model (BM). Consistent with Asongu and Ssozi (2016), reconciling the BM and WC essentially builds on the debate over the precedence of rights (political rights versus economic rights) in stages of economic development. A balanced narrative has been documented by Moyo (2013). She has defined the WC as private capitalism, liberal democracy and priority in political rights, and the $\mathrm{BM}$ as state capitalism, deemphasized democracy and priority in economic rights. According to the author, the BM or 'economic rights prioritization' should be considered in the short-run whereas political rights or the WC should be given priority only as a long-term development goal. The proposition substantially draws on the intuition that a burgeoning middle class is essential to sustainably hold governments accountable as well as to demand political rights (see Asongu 2016a).

In the light of the above, without the building of a sustainable middle class, governments cannot feasibly be held accountable because the process of democratization may be hijacked by demands for economic rights. In such a scenario, votes of the electorate are very likely to be traded for basic economic needs like food and shelter. It follows that genuine political rights 
within the framework of liberal democracy is incompatible with low income countries or nations at the early stages of industrialization. Moreover, the underlying reconciliation builds on the fact that the BM has delivered a burgeoning middle class within a historically very short period of time. The authors have further argued that liberal democracy per se was effective in the United States of America only about 170 years after independence, notably when the country had become industrialized. There is also an evolving stream of literature confirming the above discourse with a consensus that globalization has induced developed nations to be focused on political rights, as opposed to low-income countries which are more concerned with socioeconomic rights. This conclusion has been established in developing and African countries by Lalountas et al. (2011) and Asongu (2014a) respectively. Furthermore, confirmation of the precedence of economic rights over political rights in stages of development have been substantiated at continental (Anyanwu and Erhijakpor 2014) and country-specific (Kramon 2009) levels.

The above discourse is consistent with the longstanding debate over the influence of political regimes in government quality (GQ). The debate has fundamentally centered on whether democratic countries enjoy better GQ compared to their authoritarian counterparts. To this end, many theoretical initiatives have been developed to substantiate why democracies are more likely to enjoy higher GQ levels, compared to autocracies. Whereas there is some consensus on the edge of democracies over autocracies, the empirical literature is clouded with controversies. In essence, qualitative literature has provided exhaustive case studies depicting how corruption (GQ) has increased (decreased) with the advent of democracy. This is the case of: (i) many developing countries in Africa (Lemarchand 1972), Southeast Asia (Scott 1972), India (Wade 1985) and Turkey (Sayari 1977); (ii) post 1990 communist countries like Russia (Varsee 1997) and (iii) many Latin American countries upon different waves of democratization (Weyland 1998). These tendencies have inspired a number of quantitative studies, with some confirming the contradictory relationship between democracy and corruption (Harris-White 1996, 3; Sung 2004, 179). Some protagonists have articulated the existence of a non-linear relationship between democracy and GQ at the early stages of democratization. However, this negative impact becomes positive as democracy grows. Two explanations have been put forward and tested independently to elucidate this non-linear relationship: the time and level hypotheses (Asongu 2015). 
Concerning the level of democracy hypothesis, it has been established using continuous measures of political-regimes that GQ is highest in strongly democratic states, medium in strongly authoritarian regimes and least in states that are partially democratized. Based on varying empirical specifications, this level-oriented or non-linearity position has been defined as either U-shaped (Montinola and Jackman 2002), J-shaped (Back and Hadenius 2008) or Sshaped (Sung 2004). With respect to time of exposure to or historically accumulated experience with democracy, Keefer (2007) has shown that younger democracies produce worse GQ than older ones. In summary, the general idea in this literature is that partial or young democracies perform worse (worst) than authoritarian (full or older democratic) regimes.

In the light of the above, the intriguing debate on the impact of political regimes on institutional qualities remains open. Consistent with Rothstein (2011) the debate could be summarized in the observation of Diamond (2007) that: "there is a specter haunting democracy in the world today. It is bad governance-governance that serves only the interests of a narrow ruling elite. Governance that is drenched in corruption, patronage, favoritism, and abuse of power. Governance that is not responding to the massive and long-deferred social agenda of reducing inequality and unemployment and fighting against dehumanizing poverty. Governance that is not delivering broad improvement in people's lives because it is stealing, squandering, or skewing the available resources" (199). The above scenario is most relevant to Africa because the April 2015 World Bank report on Millennium Development Goals has revealed that extreme poverty has been decreasing in all regions of world with the exception of this continent (World Bank 2015) despite two decades of growth resurgence (Fosu 2015a, 44) and processes of democracy.

The present line of inquiry contributes to existing literature by advancing the debate within the context of African countries. In essence, we investigate whether African democracies enjoy relatively better GQ compared to their less democratic counterparts. The concept of governance is relevant in policy, politics and development for a plethora of reasons (Asongu 2016b), among others: (i) success in project implementation (Denizer et al. 2013); (ii) causes of failing party democracy (Ikeanyibe 2014); (iii) understanding the determinants of belief in the promotion of democracy (Kim 2014); (iv) limiting internet and cyberspace abuse (Glen 2014); (v) the effect of term limits on services to constituencies by elected officials (Van Dusky-Allen 2014); (vi) compared to autocraticies, there is a positive correlation between 'leader turnover' 
and the volaltile policy environement (Fails 2014); (vii) good governance as solid foundation of change in society (Beal and Graham 2014); (viii) improving quality of life by better resource allocation and government (Jakubow 2014), especially for the deprived elderly (Fonchingong 2014); (ix) the politics and policies towards obtaining participatory governance (Waheduzzaman and As-Saber 2015) and (x) nations with more state intervention in religion experience lower governance standards (Tusalem 2015).

The remainder of the article is presented as follows. The theoretical highlights and clarification of the concept of governance is covered in the Theoretical Highlights and Clarification of the Concept of Governance section. The data and methodology are discussed in the Data and Methodology section. The Empirical Results section presents the empirical results and discusses policy implications. The Conclusions and Future Directions section concludes with a discussion of future research directions.

\section{Theoretical Highlights and Clarification of the Concept of Governance 2.1Theoretical highlights}

There are two main streams of theories on GQ, namely the demand-side of GQ or culturalist theories and the supply-side of GQ on political institutions. As emphasized by Charron and Lapuente (2010) in the first strand on the culturalist theoretical perspective, political institutions are fixed and changes in GQ result from social preferences and values. Thus key players are ordinary people governed by cultural values who are instrumental in determining what sort of governance they need. The prevailing values of society urge citizens to mount powerful collective actions that put pressure on the elite to provide good governance. Different social demands cannot totally explain the observed level of government quality. It is also necessary to account for the supply-side.

On the supply-side, political institutions shape GQ. In this institutionalist approach, the preferences of actors following standard rational-choice assumptions are kept fixed and variations in levels of government quality depend on how institutions shape the incentives of individuals. This implies key actors are rulers from one particular type (or sub-type) of political regime. The demanders of good governance (citizens) play, if any, a minor role as inhabitants of a country are assumed to be hard-working individuals ready to develop innovative technologies if rulers deliver good institutions (and low corruption levels). 


\subsection{Clarification of the concept of governance}

We engage this section in two principal strands, namely (i) definition of GQ and (ii) debates on the validity of GQ indicators. Consisent with Asongu (2016b), various definitions have been provided for governance. First, Dixit (2009, 5) has defined economic governance as '...structure and functioning of the legal and social institutions that support economic activity and economic transactions by protecting property rights, enforcing contracts, and taking collective action to provide physical and organizational infrastructure'. Second, in accordance with Tusalem (2015), governance embodies regulatory quality, corruption, rule of law, political instability, and bureaucratic effectiveness. Third, the concepiton and definition of governance has been improved by Fukuyama (2013) who has suggested four approachs via which GQ can be appreciated, namely: (i) procedural measures; (ii) capacity measures that entail both resources and the degree of professionalism; (iii) measures of output and (iv) bureaucractic indicators. Fourth, as far as we have reviewed, the definitions, conceptions and measures of GQ by Kaufmann et al. (2010) are the most widely employed in the literaure, notably “ (i) Political governance, which measures the election and replacement of political leaders is approximated by voice \& accountability and political stability/non-violence; (ii) Economic governance, which is the formulation and implementation of policies that deliver public commodities, is denoted by regulation quality and government effectiveness ;(iii) Institutional governance, which is defined as the respect of the State and citizens of institutions that govern interactions between them is measured by the rule of law and corruption-control" (Asongu and Nwachukwu 2015, 11).

We briefly devote some space to current debates on the construction and application of the underlying GQ variables. According to Asongu (2016b), a plethora of criticisms have arisen on the quality of GQ indicators from Kaufmann, Kraay and Mastruzzi. Fortunately, Kaufmann, Kraay and Mastruzzi have readily provided rebuttals to these criticisms in the scientific community. As far as we have reviewed, the most famous argument is by Andrew Schrank and Marcus Kurtz. We briefly discuss this investigation in four main strands, namely: "measures and mechanisms'; a reply; a defense and a rejoinder.

First, the mainstream consensus that GQ promotes economic development has been questioned by Kurtz and Schrank (2007a) who have rethought the confidence entrusted in the GQ indicators on the one hand and a solidarity in corresponding growth-governance linkages in 
empirical literature on the other. The authors have established that the Kaufmann, Kraay and Mastruzzi governance variables are problematic because they suffer from many deficiencies, among others: sampling adverse selection, perceptual biases and conceptual conflation with policy choices.

Second, in a reply to Kurtz and Schrank (2007a), Kaufmann et al. (2007a) argued that the discourse by the contending authors is lacking in substance for three main reasons. They showed that the claims on biases in the perception-based measures in the GQ variables are falsifiable, speculative and short of empirical scrutiny. They provided empirical validity for this by showing that the short-term relationship between perceptions in governance and growth discussed by the competing authors is statistically fragile and conceptually flawed. They also dimissed the empirical underpinnings of the contending authors on the governance-growth nexus.

Third, Kurtz and Schrank (2007b) responded to Kaufmann et al. (2007a) with a defense letter in which they remarked that the conceptual issues and corresponding concerns of measurement are profoundly engrained in the debate on the relationship between governance and growth.

Fourth, Kaufmann et al. (2007b) replied with a brief rejoinder by reiterating on the lack of empirical backing for the criticisms advanced by Kurtz and Schrank (2007b). According to them the concerns about potential respondent baises are not entirely restricted to the government effectiveness dimension of GQ, but extend to other governance variables as well.

In the light of the above theoretical underpinnings, definitions and clarifications, the conception and measurement of governance employed in this study are consistent with Kaufmann, Kraay and Mastruzzi.

A criticism to the use of the World Governance Indicators from the World Bank may be that they can be used interchangeably with democractic quality indicators because the Washington Consensus prioritises the quality of democracy. While this criticism seems valid from the perspective of political governance, it is not within the context of economic and institutional governance indicators. Accordingly, there is a strong linkage between governance and democratic quality within the framework of political governance. In other words, political governance is strongly associated with democracy because it is defined as the election and replacement of political leaders. Moreover, not all dimensions of political governance (political 
stability/non violence and 'voice and accountability') as measured by Kaufmann, Kraay and Mastruzzi directly reflect democratic quality. For instance, a strong dictatorship may enjoy substantial political stability with little or no 'voice and accountability,' whereas liberal democracies may enjoy strong 'voice and accountability' simultaneously with substantial political instability.

Conversely, other dimensions of governance (economic governance and institutional governance) cannot be used interchangeably with democratic quality. This is because the conceptions, definitions and measurements of economic and institutional governances are quite different. Economic governance is the formulation and implementation of policies that deliver public goods and services whereas Institutional governance is the respect by State and citizens of institutions that govern interactions between them. The ideas above can be further substantiated with differences between the Washington Consensus (which prioritizes political governance) and the Beijing Model (which prioritizes economic governance). In the light of the foregoing, whereas political governance could be linked to democracy, it is not the case with economic governance and institutional governance.

\section{Data and Methodology}

\subsection{Data}

We examine a panel of 38 African countries using data from the African Development Indicators (ADI) of the World Bank (WB) for the period 1994 to 2010. In line with Kaufmann et al. (2010), GQ dependent variables include: corruption-control, government-effectiveness, voice and accountability, political stability or no violence, rule of law and regulation quality. The Kaufmann indicators from World Governance Indicators are used because (i) of their wide usage in the governance literature and (ii) they are freely accessible. Other sources of governance indicators (e.g.the International Country Risk Guide) are not free of charge.

Consistent with Yang (2011), independent variables are political regime indicators of democracy, polity and autocracy. Instrumental variables include: legal-origins, press-freedoms, income-levels and religious-dominations. These instruments have been substantially documented in the economic development literature (La Porta et al. 1997; Stulz and Williamson 2003; Beck 
et al. 2003) and have been recently employed in the African institutional literature (Asongu 2012).

In the regressions, we control for GDP growth, public investment and population growth in the first stage but not in the second-stage. The absence of control variables in the second stage has two justifications. First, from a theoretical standpoint, we need at least four instruments for the three endogenous variables to enable an over-identification restrictions (OIR) test needed for the assessment of the validity of instruments. Second, Beck et al. (2003) have followed a similar approach by not including all the control variables at the second-stage. The choices of GDP growth and population growth are consistent with Asongu (2012) whereas public investment is selected based on evidence from Asongu (2014b). The choice of the control variables are also constrained by the degrees of freedom needed for the OIR test at the second-stage of regressions. In essence given the number of instruments under consideration, including control variables at the second-stage would either result in exact- or under-identification: implying that the instruments are either equal to or less than the number of endogenous explaining variables respectively.

Definitions and sources of variables are presented in Appendix 1, while summary statistics are disclosed in Appendix 2. A correlation matrix is provided in Appendix 3 while categorization of countries is disclosed in Appendix 4. Two insights are worth noting from the summary statistics (i) the variables are comparable from mean values and (ii) the substantial variations imply we can be confident that reasonable estimated linkages would emerge. The purpose of the correlation matrix is to limit potential multicollinearity issues.

\subsection{Methodology}

While political regimes shape the quality of institutions, the reverse effect is also true because constraints in institutional quality might affect the political powers in charge. For instance an investigation into corruption allegations by an independent investigation committee might unveil some very nasty aspects of government that could result in a change in politicalregime, either by popular revolt or resignation of culprits within the government. Thus, an important issue of endogeneity results from this fact and should be taken into account by the estimation technique to avoid biased estimates. 
Consistent with Beck et al. (2003) the paper adopts an Instrumental Variable (IV) estimation technique. IV estimates address the puzzle of endogeneity and thus avoid the inconsistency of estimated coefficients by Ordinary Least Squares (OLS) when the independent variables are correlated with the error term in the equation of interest. The corresponding TwoStage-Least-Squares (2SLS) IV estimation method adopted entails the following steps.

First-stage regression:

$$
\begin{aligned}
\text { PoliticalChannel }_{i t}= & \gamma_{0}+\gamma_{1}(\text { legalorigin })_{i t}+\gamma_{2}\left(\text { religion }_{i t}+\gamma_{3}\left(\text { (incomelevel }_{i t}\right.\right. \\
& +\gamma_{4}(\text { pressfreedom })_{i t}+\alpha_{i} X_{i t}+v
\end{aligned}
$$

Second-stage regression:

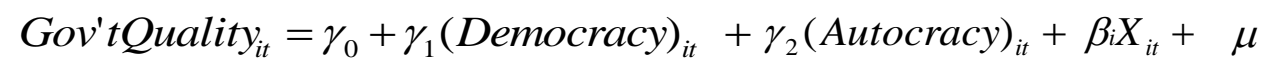

In the two equations, $X$ is a set of exogenous control variables. For both the first and second equations, $v$ and $u$ respectively represent the error terms. Instrumental variables are legal-origins, religious domination, income-levels and press-freedoms.

We adopt the following steps in the analysis: (i) justify the use of a 2SLS-IV over an OLS estimation technique with the Hausman-test for endogeneity; (ii) show that the instruments explain the endogenous components of explaining variables (political-regime channels), conditional on other covariates (control variables) and (iii) using an OIR test to assess the validity of the instruments by investigating whether they are correlated with the errors in the equation of interest. For the purpose of further robustness checks, we employ: two sets of instruments; robust Heteroscedasticity and Autocorrelation Consistent (HAC) standard errors and Fixed Effects regressions.

\section{Empirical Results}

This section addresses: (i) the ability of exogenous components of political-regimes to account for differences in GQ; (ii) the ability of the instruments to explain variations in the endogenous components of political-regimes and (iii) the possibility of the instruments to account for GQ beyond political-regime channels. In order to make these assessments, we use the 2SLS-IV estimation technique with legal-origins, press-freedoms, income-levels and religious-dominations as instrumental variables. 


\subsection{Quality of government and instruments}

Table 1 assesses the importance of the instruments in explaining differences in GQ. It is apparent that distinguishing African countries by legal-origins, income-levels, press-freedoms and religious-denominations helps explain cross-country difference in GQ. The instruments taken together enter significantly into all regressions at the 1 percent significance level.

The following findings can be established. (i) English common-law countries have better levels of GQ, compared to their French civil-law counterparts. This is consistent with the lawfinance (growth) literature (La Portal et al. 1997; La Portal et al. 1998; Beck et al. 2003) and recent African law-development literature (Agbor 2015). (ii) With the exception of governmenteffectiveness, the dominance of Christian nations over their Islam-oriented counterparts is not very significant. Conversely, the significance aspect is broadly consistent with El Badawi and Makdisi (2007). (iii) Consistent with Narayan et al. (2011), GQ increases with income-levels. (iv) Contrary to Vaidya (2005) and Oscarsson (2008), GQ improves with press-freedoms.

\subsection{Political-regimes and instruments}

In Table 2 we regress the political-regime indicators on the instruments and test for their joint significance. This is the first-stage (or requirement) of the IV estimation technique in which the endogenous components of the independent variables must be explained by the instruments, conditional on other covariates (control variables). Based on the results of the Fisher-statistics, it is established that the instruments are strong because in the presence of control variables the instruments jointly enter significantly into all regressions at the 1 percent significance level. Thus, employing underlying instruments helps account for cross-country differences in the quality and nature of political institutions in Africa. Like with the GQ-instrument regressions, we engage two separate regressions for each political regime dynamic in the presence and absence of control variables such that we have four regressions for each dynamic. The following findings are established. (i) Consistent with the law-finance(growth) literature (La Portal et al. 1997; La Portal et al. 1998; Beck et al. 2003; Agbor 2015), English common law countries have higher levels of democracy than their French civil law counterparts. (ii) Christian-dominated countries enjoy higher (lower) levels of democracy (autocracy) compared to their Islam-oriented counterparts. This finding is consistent with El Badawi and Makdisi (2007). (iii) In accordance 
with Narayan et al. (2011), democracy increases with income-levels. Democratic institutions improve with press-freedoms: contrary to Vaidya (2005) and Oscarsson (2008).

\subsection{The Quality of government and politics}

Table 3 assesses two main issues (i) the ability of political-regime channels to account for GQ dynamics and (ii) the possibility of the instrumental variables explaining GQ dynamics beyond political-regime channels. While the first issue is addressed by the significance of estimated coefficients, the second is tackled with the OIR test. The null hypothesis of this test is the position that the instruments account for GQ dynamics only through political regime channels. Thus a rejection of the null hypothesis is a denunciation of the view that the instruments explain GQ dynamics through no other mechanisms than political-regime channels. The choice of the 2SLS technique is contingent on the outcome of the Hausman test for endogeneity. The null hypothesis of this test is the position that OLS estimates are efficient and consistent. Therefore a rejection of the null hypothesis confirms the issue of reverse causality (endogeneity) we highlighted earlier and hence justifies an IV estimation technique. The following measures are adopted to ensure goodness of fit and robustness of estimated coefficients. (i) Every specification is replicated using an alternative set of instrumental variables as disclosed in the second- and third-to-the last lines of Table 3. (ii) Robust HAC standard errors (Panel B) are used to check results of the 2SLS in Panel A. (3) Based on the outcome of the Hausamn test, the FE regressions (which assume that the explaining variables are correlated with the error-term) are used to further check the results in Panel A and Panel B.

The first issue which is addressed with the significance of estimated coefficients could be summarized as follows, (i) compared to authoritarian regimes, democracies have a more significant impact on GQ dynamics and (ii) authoritarian regimes have an edge over Polity in the 2SLS (Panels A and B), whereas both overlap in FE regressions. Concerning the second issue, two interpretations are apparent. (i) The instruments explain government effectiveness and political stability beyond political regime channels. This implies that there are other mechanisms by which the instruments explain GQ dynamics of government-effectiveness and politicalstability beside political regime channels.

With respect to the other GQ dynamics, the instruments do not explain them beyond political regime channels. This implies the instrumental variables are valid and not correlated 
with the error term in the equation of interest. In other words, the instruments explain the remaining GQ dynamics through no other mechanisms than political regime channels. 
Table 1. The quality of government and instruments

\begin{tabular}{|c|c|c|c|c|c|c|c|c|c|c|c|c|c|}
\hline & \multirow[b]{2}{*}{ Constant } & \multicolumn{2}{|c|}{ Control of Corruption } & \multirow{2}{*}{$\begin{array}{l}\text { Government } \\
\\
-1.665 * * * \\
(-13.86)\end{array}$} & \multirow{2}{*}{$\begin{array}{l}\text { Effectiveness } \\
\\
-0.319 * * * \\
(-3.285)\end{array}$} & \multicolumn{2}{|c|}{ Voice \& Accountability } & \multicolumn{2}{|c|}{ Political Stability } & \multicolumn{2}{|c|}{ Regulation Quality } & \multicolumn{2}{|c|}{ Rule of Law } \\
\hline & & $\begin{array}{l}-1.219 * * * \\
(-8.868)\end{array}$ & $\begin{array}{l}-0.260 * * \\
(-2.381)\end{array}$ & & & $\begin{array}{l}-1.402 * * * \\
(-21.17)\end{array}$ & $\begin{array}{l}0.041 \\
(0.404)\end{array}$ & $\begin{array}{l}-1.614 * * * \\
(-13.01)\end{array}$ & $\begin{array}{l}-0.572 * * * \\
(-4.119)\end{array}$ & $\begin{array}{l}-1.156 * * * \\
(-15.57)\end{array}$ & $\begin{array}{l}-0.169 * * \\
(-2.016)\end{array}$ & $\begin{array}{l}-1.522 * * * \\
(-19.95)\end{array}$ & $\begin{array}{l}-0.430 * * * \\
(-4.846)\end{array}$ \\
\hline \multirow{2}{*}{$\begin{array}{l}\text { Legal- } \\
\text { origins }\end{array}$} & English common-law & $\begin{array}{l}\text { 0.193**** } \\
(3.624)\end{array}$ & --- & $\begin{array}{l}0.317 * * * \\
(6.816)\end{array}$ & --- & $\begin{array}{l}\text { 0.149**** } \\
(\mathbf{3 . 3 5 5 )}\end{array}$ & --- & $\begin{array}{l}0.119 \\
(1.433)\end{array}$ & --- & $\begin{array}{l}0.335 * * * \\
(6.757)\end{array}$ & --- & $\begin{array}{l}0.347 * * * \\
(6.771)\end{array}$ & --- \\
\hline & French civil-law & -- & $\begin{array}{l}-0.210 * * * * \\
(-3.778)\end{array}$ & --- & $\begin{array}{l}-0.335 * * * \\
(-6.777)\end{array}$ & --- & $\begin{array}{l}-0.175 * * * \\
(-3.325)\end{array}$ & --- & $\begin{array}{l}-0.150 * \\
(-1.778)\end{array}$ & --- & $\begin{array}{l}-0.357 * * * \\
(-7.033)\end{array}$ & --- & $\begin{array}{l}-0.377 * * * \\
(-7.033)\end{array}$ \\
\hline \multirow[t]{3}{*}{ Religions } & Christianity & $\begin{array}{l}-0.010 \\
(-0.179)\end{array}$ & --- & $\begin{array}{l}\text { 0.098* } \\
(1.892)\end{array}$ & --- & $\begin{array}{l}0.0312 \\
(0.619)\end{array}$ & --- & $\begin{array}{l}-0.019 \\
(-0.210)\end{array}$ & --- & $\begin{array}{l}0.036 \\
(0.645)\end{array}$ & --- & $\begin{array}{l}0.002 \\
(0.043)\end{array}$ & --- \\
\hline & Islam & --- & $\begin{array}{l}0.023 \\
(0.380)\end{array}$ & --- & $\begin{array}{l}-0.085 \\
(-1.533)\end{array}$ & --- & $\begin{array}{l}-0.005 \\
(-0.093)\end{array}$ & --- & $\begin{array}{l}0.023 \\
(0.248)\end{array}$ & --- & $\begin{array}{l}-0.032 \\
(-0.563)\end{array}$ & --- & $\begin{array}{l}0.002 \\
(0.045)\end{array}$ \\
\hline & Low Income & --- & $\begin{array}{l}-0.183 * * * \\
(-2.674)\end{array}$ & --- & $\begin{array}{l}-0.272 * * * \\
(-4.456)\end{array}$ & --- & $\begin{array}{l}-0.022 \\
(-0.352)\end{array}$ & --- & $\begin{array}{l}-0.180 * \\
(-1.839)\end{array}$ & --- & $\begin{array}{l}-0.068 \\
(-1.158)\end{array}$ & --- & $\begin{array}{l}-0.164 * * * \\
(-2.633)\end{array}$ \\
\hline \multirow{4}{*}{$\begin{array}{l}\text { Income } \\
\text { Levels }\end{array}$} & Middle Income & $\begin{array}{l}\mathbf{0 . 3 3 5} * * * \\
(3.984)\end{array}$ & --- & $\begin{array}{l}0.467 * * * \\
(6.346)\end{array}$ & --- & $\begin{array}{l}\text { 0.116* } \\
(1.672)\end{array}$ & --- & $\begin{array}{l}\text { 0.599**** } \\
(4.613)\end{array}$ & --- & $\begin{array}{l}0.349 * * * \\
(4.510)\end{array}$ & --- & $\begin{array}{l}\mathbf{0 . 4 2 0} * * * \\
(\mathbf{5 . 2 5 8})\end{array}$ & --- \\
\hline & Lower Middle Income & $\begin{array}{l}-0.119 \\
(-1.309)\end{array}$ & --- & $\begin{array}{l}-0.160 * * \\
(-2.009)\end{array}$ & --- & $\begin{array}{l}-0.030 \\
(-0.388)\end{array}$ & --- & $\begin{array}{l}-0.404 * * * \\
(-2.762)\end{array}$ & --- & $\begin{array}{l}-0.271 * * * \\
(-3.108)\end{array}$ & --- & $\begin{array}{l}-0.242 * * * \\
(-2.687)\end{array}$ & --- \\
\hline & Upper Middle Income & --- & $\begin{array}{l}0.288 * * * \\
(3.217)\end{array}$ & --- & $\begin{array}{l}0.338 * * * * \\
(4.248)\end{array}$ & --- & $\begin{array}{l}0.320 * * * \\
(3.769)\end{array}$ & --- & $\begin{array}{l}0.594 * * * \\
(4.292)\end{array}$ & --- & $\begin{array}{l}0.407 * * * \\
(4.856)\end{array}$ & --- & $\begin{array}{l}0.437 * * * * \\
(4.923)\end{array}$ \\
\hline & Free & $\begin{array}{l}0.835 * * * \\
(10.44)\end{array}$ & -- & $\begin{array}{l}0.912 * * * \\
(13.06)\end{array}$ & --- & $\begin{array}{l}1.632 * * * \\
(24.12)\end{array}$ & --- & $\begin{array}{l}1.118 * * * \\
(8.824)\end{array}$ & --- & $\begin{array}{l}0.791 * * * \\
(10.48)\end{array}$ & --- & $\begin{array}{l}0.929 * * * \\
(11.92)\end{array}$ & -- \\
\hline \multirow[t]{3}{*}{$\begin{array}{l}\text { Press } \\
\text { Freedoms }\end{array}$} & Partly Free & $\begin{array}{l}\text { 0.395**** } \\
(7.115)\end{array}$ & --- & $\begin{array}{l}0.447 * * * \\
(9.213)\end{array}$ & --- & $\begin{array}{l}0.887 * * * \\
(18.76)\end{array}$ & --- & $\begin{array}{l}\text { 0.632**** } \\
(7.140)\end{array}$ & --- & $\begin{array}{l}0.453 * * * \\
(8.584)\end{array}$ & --- & $\begin{array}{l}\text { 0.444*** } \\
(8.158)\end{array}$ & --- \\
\hline & No Freedom & --- & $\begin{array}{l}-0.505 * * * \\
(-9.368)\end{array}$ & -- & $\begin{array}{l}-0.563 * * * \\
(-11.73)\end{array}$ & --- & $\begin{array}{l}-1.071 * * * \\
(-20.99)\end{array}$ & --- & $\begin{array}{l}-0.759 * * * \\
(-9.126)\end{array}$ & -- & $\begin{array}{l}-0.539 * * * \\
(-10.69)\end{array}$ & -- & $\begin{array}{l}-0.567 * * * \\
(-10.63)\end{array}$ \\
\hline & GDP Growth & $\begin{array}{l}-\mathbf{0 . 0 1 4} * * * \\
(-2.858)\end{array}$ & $\begin{array}{l}-0.014 * * * \\
(-2.750)\end{array}$ & $\begin{array}{l}-0.008 * \\
(-1.940)\end{array}$ & $\begin{array}{l}-0.008 * \\
(-1.836)\end{array}$ & $\begin{array}{l}-0.006 * \\
(-1.731)\end{array}$ & $\begin{array}{l}-0.006 \\
(-1.329)\end{array}$ & $\begin{array}{l}-0.001 \\
(-0.150)\end{array}$ & --- & $\begin{array}{l}-0.008 * \\
(-1.914)\end{array}$ & $\begin{array}{l}-0.009 * * \\
(-2.073)\end{array}$ & $\begin{array}{l}-0.009 * * \\
(-2.095)\end{array}$ & $\begin{array}{l}-0.010 * * \\
(-2.276)\end{array}$ \\
\hline \multirow[t]{5}{*}{$\begin{array}{l}\text { Control } \\
\text { Variables }\end{array}$} & Population Growth & $\begin{array}{l}-0.020 \\
(-0.586)\end{array}$ & $\begin{array}{l}-0.054 \\
(-1.480)\end{array}$ & $\begin{array}{l}0.050 \\
(1.620)\end{array}$ & $\begin{array}{l}0.015 \\
(0.467)\end{array}$ & --- & $\begin{array}{l}-0.062 * \\
(-1.791)\end{array}$ & -- & --- & --- & --- & --- & --- \\
\hline & Public Investment & $\begin{array}{l}\text { 0.041**** } \\
(5.556)\end{array}$ & $\begin{array}{l}\text { 0.041**** } \\
(5.387)\end{array}$ & $\begin{array}{l}\text { 0.036**** } \\
(\mathbf{5 . 5 6 0 )}\end{array}$ & $\begin{array}{l}\text { 0.036**** } \\
(5.301)\end{array}$ & $\begin{array}{l}\text { 0.021**** } \\
(3.684)\end{array}$ & $\begin{array}{l}\text { 0.021**** } \\
(\mathbf{3 . 0 5 7})\end{array}$ & $\begin{array}{l}0.070 * * * * \\
(6.321)\end{array}$ & $\begin{array}{l}\mathbf{0 . 0 7 0} * * * * \\
(6.367)\end{array}$ & $\begin{array}{l}0.015 * * \\
(2.389)\end{array}$ & $\begin{array}{l}0.016 * * \\
(2.404)\end{array}$ & $\begin{array}{l}0.047 * * * \\
(6.934)\end{array}$ & $\begin{array}{l}0.048 * * * * \\
(6.688)\end{array}$ \\
\hline & Adjusted $\mathrm{R}^{2}$ & 0.475 & 0.430 & 0.601 & 0.549 & 0.742 & 0.655 & 0.409 & 0.387 & 0.499 & 0.471 & 0.569 & 0.521 \\
\hline & Fisher test & $34.293 * * *$ & $32.128 * * *$ & $56.236 * * *$ & $51.261 * * *$ & $123.046 * * *$ & $81.255^{* * * *}$ & $30.293 * * *$ & $36.656 * * *$ & 43.00*** & $43.950 * * *$ & $56.789 * * *$ & $53.700 * * *$ \\
\hline & Observations & 331 & 331 & 331 & 331 & 339 & 339 & 339 & 339 & 338 & 338 & 339 & 339 \\
\hline
\end{tabular}


Table 2. First-stage regressions

\begin{tabular}{|c|c|c|c|c|c|c|c|c|c|c|c|c|c|}
\hline & \multirow[b]{2}{*}{ Constant } & \multicolumn{4}{|c|}{ Democracy } & \multicolumn{4}{|c|}{ Polity } & \multicolumn{4}{|c|}{ Autocracy } \\
\hline & & $\begin{array}{l}0.150 \\
(0.455)\end{array}$ & $\begin{array}{l}-1.317 * * * \\
(-2.911)\end{array}$ & $\begin{array}{l}4.287 * * * \\
(10.27)\end{array}$ & $\begin{array}{l}3.293 * * * * \\
(6.082)\end{array}$ & $\begin{array}{l}-2.578 * * * \\
(-6.504)\end{array}$ & $\begin{array}{l}-3.226 * * * \\
(-5.870)\end{array}$ & $\begin{array}{l}3.069 * * * \\
(6.025)\end{array}$ & $\begin{array}{l}2.672 * * * * \\
(3.434)\end{array}$ & $\begin{array}{l}2.748 * * * \\
(8.204)\end{array}$ & $\begin{array}{l}2.134 * * * * \\
(3.677)\end{array}$ & $\begin{array}{l}1.293 * * * \\
(3.158)\end{array}$ & $\begin{array}{l}1.222 * * \\
(2.465)\end{array}$ \\
\hline \multirow{2}{*}{$\begin{array}{l}\text { Legal- } \\
\text { origins }\end{array}$} & English common-law & $\begin{array}{l}0.660 * * \\
(2.168)\end{array}$ & $\begin{array}{l}\mathbf{0 . 6 7 7 * *} \\
(2.163)\end{array}$ & --- & --- & $\begin{array}{l}-0.029 \\
(-0.080)\end{array}$ & $\begin{array}{l}-0.182 \\
(-0.480)\end{array}$ & --- & --- & $\begin{array}{l}0.710 * * \\
(2.304)\end{array}$ & $\begin{array}{l}0.789 * * \\
(2.557)\end{array}$ & --- & -- \\
\hline & French civil-law & --- & --- & $\begin{array}{l}-0.897 * * * \\
(-2.847)\end{array}$ & $\begin{array}{l}-0.951 * * * \\
(-2.929)\end{array}$ & --- & --- & $\begin{array}{l}-0.314 \\
(-0.817)\end{array}$ & $\begin{array}{l}-0.098 \\
(-0.241)\end{array}$ & --- & --- & $\begin{array}{l}-0.600 * \\
(-1.942)\end{array}$ & $\begin{array}{l}-0.837 * * * \\
(-2.596)\end{array}$ \\
\hline \multirow[t]{3}{*}{ Religions } & Christianity & $\begin{array}{l}0.089 \\
(0.275)\end{array}$ & $\begin{array}{l}0.079 \\
(0.227)\end{array}$ & --- & --- & $\begin{array}{l}1.167 * * * \\
(3.009)\end{array}$ & $\begin{array}{l}\text { 1.038** } \\
(\mathbf{2 . 4 5 1 )}\end{array}$ & --- & --- & $\begin{array}{l}-1.024 * * * * \\
(-3.123)\end{array}$ & $\begin{array}{l}-0.982 * * * \\
(-3.012)\end{array}$ & --- & --- \\
\hline & Islam & --- & --- & $\begin{array}{l}-0.039 \\
(-0.117)\end{array}$ & $\begin{array}{l}0.047 \\
(0.128)\end{array}$ & --- & --- & $\begin{array}{l}-1.094 * * * \\
(-2.663)\end{array}$ & $\begin{array}{l}-0.799 * \\
(-1.771)\end{array}$ & --- & --- & $\begin{array}{l}\text { 1.000*** } \\
(\mathbf{3 . 0 2 8})\end{array}$ & $\begin{array}{l}0.923 * * \\
(2.517)\end{array}$ \\
\hline & Low Income & --- & --- & $\begin{array}{l}\mathbf{0 . 8 6 8 * *} \\
(2.297)\end{array}$ & $\begin{array}{l}0.292 \\
(0.725)\end{array}$ & --- & --- & $\begin{array}{l}1.536 * * * \\
(3.333)\end{array}$ & $\begin{array}{l}1.748 * * * \\
(3.439)\end{array}$ & --- & --- & $\begin{array}{l}-0.644 * \\
(-1.738)\end{array}$ & $\begin{array}{l}-0.951 * * \\
(-2.361)\end{array}$ \\
\hline \multirow{4}{*}{$\begin{array}{l}\text { Income } \\
\text { Levels }\end{array}$} & Middle Income & $\begin{array}{l}0.251 \\
(0.508)\end{array}$ & $\begin{array}{l}0.321 \\
(0.642)\end{array}$ & -- & --- & $\begin{array}{l}-1.406 * * \\
(-2.373)\end{array}$ & $\begin{array}{l}-0.987 \\
(-1.624)\end{array}$ & --- & --- & $\begin{array}{l}1.590 * * * \\
(3.175)\end{array}$ & $\begin{array}{l}1.295 * * \\
(2.514)\end{array}$ & --- & --- \\
\hline & Lower Middle Income & $\begin{array}{l}-0.872 \\
(-1.512)\end{array}$ & $\begin{array}{l}-0.392 \\
(-0.664)\end{array}$ & --- & --- & $\begin{array}{l}0.228 \\
(0.331)\end{array}$ & $\begin{array}{l}-0.213 \\
(-0.298)\end{array}$ & --- & --- & $\begin{array}{l}-1.061^{*} \\
(-1.818)\end{array}$ & $\begin{array}{l}-0.744 \\
(-1.270)\end{array}$ & --- & --- \\
\hline & Upper Middle Income & --- & --- & $\begin{array}{l}2.535 * * * \\
(4.652)\end{array}$ & $\begin{array}{l}2.157 * * * \\
(3.853)\end{array}$ & --- & --- & $\begin{array}{l}2.183 * * * * \\
(3.284)\end{array}$ & $\begin{array}{l}2.541 * * * * \\
(3.636)\end{array}$ & --- & -- & $\begin{array}{l}0.285 \\
(0.533)\end{array}$ & $\begin{array}{l}-0.561 \\
(-0.996)\end{array}$ \\
\hline & Free & $\begin{array}{l}6.997 * * * \\
(13.64)\end{array}$ & $\begin{array}{l}\mathbf{6 . 8 8 4} * * * * \\
(13.34)\end{array}$ & --- & --- & $\begin{array}{l}10.025 * * * \\
(16.31)\end{array}$ & $\begin{array}{l}\text { 9.694**** } \\
(15.47)\end{array}$ & --- & --- & $\begin{array}{l}-3.067 * * * * \\
(-5.905)\end{array}$ & $\begin{array}{l}-2.892 * * * \\
(-5.548)\end{array}$ & --- & --- \\
\hline \multirow[t]{3}{*}{$\begin{array}{l}\text { Press } \\
\text { Freedoms }\end{array}$} & Partly Free & $\begin{array}{l}3.464 * * * \\
(11.00)\end{array}$ & $\begin{array}{l}3.185 * * * \\
(9.567)\end{array}$ & --- & --- & $\begin{array}{l}4.899 * * * \\
(12.99)\end{array}$ & $\begin{array}{l}4.420 * * * \\
(10.94)\end{array}$ & --- & --- & $\begin{array}{l}-1.417 * * * \\
(-4.444)\end{array}$ & $\begin{array}{l}-1.369 * * * * \\
(-4.331)\end{array}$ & --- & --- \\
\hline & No Freedom & --- & --- & $\begin{array}{l}-4.137 * * * \\
(-13.28)\end{array}$ & $\begin{array}{l}-3.943 * * * \\
(-11.99)\end{array}$ & --- & --- & $\begin{array}{l}-5.875^{* * * *} \\
(-15.46)\end{array}$ & $\begin{array}{l}-5.505 * * * \\
(-13.53)\end{array}$ & --- & -- & $\begin{array}{l}1.731 * * * \\
(5.667)\end{array}$ & $\begin{array}{l}1.491 * * * \\
(4.605)\end{array}$ \\
\hline & GDP Growth & --- & $\begin{array}{l}0.020 \\
(0.977)\end{array}$ & --- & --- & --- & $\begin{array}{l}-0.059 * * \\
(-2.316)\end{array}$ & --- & $\begin{array}{l}-0.047 \\
(-1.627)\end{array}$ & --- & $\begin{array}{l}0.068 * * * \\
(3.164)\end{array}$ & --- & $\begin{array}{l}\mathbf{0 . 0 7 3} * * * * \\
(\mathbf{3 . 2 1 4})\end{array}$ \\
\hline \multirow[t]{5}{*}{$\begin{array}{l}\text { Control } \\
\text { Variables }\end{array}$} & Population Growth & --- & --- & --- & --- & --- & --- & --- & $\begin{array}{l}-0.423 * * \\
(-1.998)\end{array}$ & --- & $\begin{array}{l}0.083 \\
(0.501)\end{array}$ & --- & --- \\
\hline & Public Investment & --- & $\begin{array}{l}0.188 * * * \\
(4.658)\end{array}$ & --- & $\begin{array}{l}0.188 * * * * \\
(4.501)\end{array}$ & --- & $\begin{array}{l}0.166 * * * \\
(3.390)\end{array}$ & --- & $\begin{array}{l}\text { 0.151**** } \\
(\mathbf{2 . 8 8 5})\end{array}$ & --- & --- & --- & $\begin{array}{l}0.021 \\
(1.334)\end{array}$ \\
\hline & Adjusted $\mathrm{R}^{2}$ & 0.381 & 0.412 & 0.329 & 0.353 & 0.433 & 0.449 & 0.363 & 0.375 & 0.087 & 0.105 & 0.072 & 0.098 \\
\hline & Fisher test & $57.936 * * *$ & $44.971 * * *$ & $55.447 * * *$ & $46.688 * * *$ & $71.792 * * *$ & $52.108 * * *$ & $64.355 * * *$ & $38.706 * * *$ & $9.905 * * *$ & $9.150 * * *$ & $9.721 * * *$ & $8.831 * * *$ \\
\hline & Observations & 555 & 502 & 555 & 502 & 555 & 502 & 555 & 502 & 555 & 555 & 555 & 500 \\
\hline
\end{tabular}


Table 3. Second-stage regressions

\begin{tabular}{|c|c|c|c|c|c|c|c|c|c|c|c|c|}
\hline \multirow[b]{3}{*}{ Constant } & \multicolumn{12}{|c|}{$\begin{array}{c}\text { Panel A: 2SLS } \\
\end{array}$} \\
\hline & \multicolumn{2}{|c|}{ Control of Corruption } & \multirow{2}{*}{$\begin{array}{l}\text { Government } \\
-1.514 * * * * \\
(-9.550)\end{array}$} & \multirow{2}{*}{$\begin{array}{l}\text { Effectiveness } \\
-1.559 * * * * \\
(-9.548)\end{array}$} & \multicolumn{2}{|c|}{ Voice \& Accountability } & \multicolumn{2}{|c|}{ Political Stability } & \multicolumn{2}{|c|}{ Regulation Quality } & \multicolumn{2}{|c|}{ Rule of Law } \\
\hline & $\begin{array}{l}-1.320 * * * \\
(-8.349)\end{array}$ & $\begin{array}{l}-1.358 * * * * \\
(-8.307)\end{array}$ & & & $\begin{array}{l}-1.259 * * * \\
(-10.39)\end{array}$ & $\begin{array}{l}-1.308 * * * \\
(-10.41)\end{array}$ & $\begin{array}{l}-1.467 * * * \\
(-7.390)\end{array}$ & $\begin{array}{l}-1.522 * * * * \\
(-7.383)\end{array}$ & $\begin{array}{l}-1.375 * * * \\
(-7.635)\end{array}$ & $\begin{array}{l}-1.421 * * * * \\
(-7.584)\end{array}$ & $\begin{array}{l}-1.701 * * * * \\
(-7.881)\end{array}$ & $\begin{array}{l}-1.758 * * * * \\
(-7.820)\end{array}$ \\
\hline Democracy & $\begin{array}{l}0.161 * * * \\
(6.921)\end{array}$ & -- & $\begin{array}{l}\mathbf{0 . 1 8 8} * * * * \\
(\mathbf{7 . 8 5 4 )}\end{array}$ & -- & $\begin{array}{l}0.219 * * * \\
(12.28)\end{array}$ & & $\begin{array}{l}0.218 * * * \\
(7.455)\end{array}$ & --- & $\begin{array}{l}0.184 * * * \\
(6.980)\end{array}$ & --- & $\begin{array}{l}0.216 * * * \\
(6.793)\end{array}$ & -- \\
\hline Polity & --- & $\begin{array}{l}\mathbf{0 . 1 6 6 * * *} \\
(6.902)\end{array}$ & --- & $\begin{array}{l}0.194 * * * \\
(7.868)\end{array}$ & --- & $\begin{array}{l}\mathbf{0 . 2 2 5} * * * \\
(12.19)\end{array}$ & --- & $\begin{array}{l}0.225 * * * \\
(7.425)\end{array}$ & --- & $\begin{array}{l}0.191 * * * \\
(6.935)\end{array}$ & --- & $\begin{array}{l}0.223 * * * \\
(6.758)\end{array}$ \\
\hline Autocracy & $\begin{array}{l}\text { 0.126** } \\
(2.131)\end{array}$ & $\begin{array}{l}\text { 0.301**** } \\
(3.737)\end{array}$ & $\begin{array}{l}0.151 * * * \\
(2.665)\end{array}$ & $\begin{array}{l}0.355 * * * \\
(4.588)\end{array}$ & $\begin{array}{l}-0.0001 \\
(-0.003)\end{array}$ & $\begin{array}{l}\text { 0.237**** } \\
(3.888)\end{array}$ & $\begin{array}{l}0.149 * * \\
(2.067)\end{array}$ & $\begin{array}{l}\text { 0.388**** } \\
(\mathbf{3 . 8 8 4})\end{array}$ & $\begin{array}{l}\text { 0.149** } \\
(2.282)\end{array}$ & $\begin{array}{l}0.352 * * * \\
(3.874)\end{array}$ & $\begin{array}{l}0.209 * * * \\
(2.666)\end{array}$ & $\begin{array}{l}0.447 * * * \\
(4.103)\end{array}$ \\
\hline $\begin{array}{l}\text { Hausman test } \\
\text { OIR-Sargan } \\
\text { P-value } \\
\text { Cragg-Donald } \\
\text { Adjusted R }{ }^{2} \\
\text { Fisher } \\
\text { Observations } \\
\end{array}$ & $\begin{array}{l}\mathbf{7 9 . 8 4 0} * * * \\
\mathbf{5 . 9 1 6} \\
{[\mathbf{0 . 2 0 5}]} \\
2.212 \\
0.170 \\
\mathbf{3 6 . 4 7 1} * * * \\
362 \\
\end{array}$ & $\begin{array}{l}\mathbf{7 8 . 8 8 6} * * * \\
\mathbf{5 . 7 9 6} \\
{[\mathbf{0 . 2 1 4}]} \\
2.198 \\
0.172 \\
\mathbf{3 6 . 2 4 6} * * * \\
362 \\
\end{array}$ & $\begin{array}{l}\mathbf{1 4 6 . 6 6} * * * \\
11.368 * * \\
{[0.022]} \\
3.094 \\
0.193 \\
\mathbf{3 9 . 4 5 6} * * * \\
352 \\
\end{array}$ & $\begin{array}{l}\mathbf{1 4 7 . 0 2 6} * * * \\
11.109 * * \\
{[0.025]} \\
3.097 \\
0.194 \\
\mathbf{3 9 . 5 6 2} * * * \\
352 \\
\end{array}$ & $\begin{array}{l}\mathbf{2 9 8 . 8 7 8} * * * \\
\mathbf{1 . 1 5 6} \\
{[\mathbf{0 . 8 8 5}]} \\
2.213 \\
0.597 \\
\mathbf{1 9 7 . 6 1 9} * * * \\
370 \\
\end{array}$ & $\begin{array}{l}\mathbf{2 9 8 . 6 7 7} * * * \\
\mathbf{1 . 2 8 5} \\
{[\mathbf{0 . 8 6 3}]} \\
2.200 \\
0.594 \\
\mathbf{1 9 4 . 8 4 5} * * * \\
370 \\
\end{array}$ & $\begin{array}{l}\mathbf{5 5 . 3 2 4} * * * \\
9.496 * * \\
{[0.049]} \\
2.213 \\
0.284 \\
\mathbf{4 6 . 6 3 7} * * * \\
370 \\
\end{array}$ & $\begin{array}{l}\mathbf{5 6 . 0 8 0} * * * \\
8.871 * \\
{[0.064]} \\
2.200 \\
0.283 \\
\mathbf{4 6 . 1 0 9} * * * \\
370 \\
\end{array}$ & $\begin{array}{l}\mathbf{1 4 8 . 1 2 4} * * * * \\
\mathbf{4 . 7 2 7} \\
{[\mathbf{0 . 3 1 6}]} \\
2.198 \\
0.186 \\
\mathbf{3 8 . 0 0 6} * * * * \\
369 \\
\end{array}$ & $\begin{array}{l}\mathbf{1 5 0 . 2 3 1} * * * \\
\mathbf{4 . 2 4 7} \\
{[\mathbf{0 . 3 7 3}]} \\
2.185 \\
0.184 \\
\mathbf{3 7 . 4 1 1} * * * \\
369 \\
\end{array}$ & $\begin{array}{l}\mathbf{1 4 5 . 4 9 1} * * * \\
\mathbf{4 . 6 7 1} \\
{[\mathbf{0 . 3 2 2}]} \\
2.213 \\
0.208 \\
\mathbf{3 2 . 4 4 1} * * * \\
370 \\
\end{array}$ & $\begin{array}{l}\mathbf{1 4 7 . 3 1 4} * * * \\
\mathbf{4 . 0 4 8} \\
{[\mathbf{0 . 3 9 9}]} \\
0.210 \\
0.210 \\
\mathbf{3 1 . 9 9 5 * * *} \\
370 \\
\end{array}$ \\
\hline \multirow{2}{*}{ Observations } & \multicolumn{12}{|c|}{ Panel B: 2SLS with HAC } \\
\hline & \multicolumn{2}{|c|}{ Control of Corruption } & Government & Effectiveness & \multicolumn{2}{|c|}{ Voice \& Accountability } & \multicolumn{2}{|c|}{ Political Stability } & \multicolumn{2}{|c|}{ Regulation Quality } & \multicolumn{2}{|c|}{ Rule of Law } \\
\hline Constant & $\begin{array}{l}-1.320 * * * \\
(-3.648)\end{array}$ & $\begin{array}{l}-1.358 * * * * \\
(-3.543)\end{array}$ & $\begin{array}{l}-1.514 * * * \\
(-4.422)\end{array}$ & $\begin{array}{l}-1.559 * * * \\
(-4.363)\end{array}$ & $\begin{array}{l}-1.259 * * * \\
(-5.945)\end{array}$ & $\begin{array}{l}-1.308 * * * \\
(-5.657)\end{array}$ & $\begin{array}{l}-1.467 * * * \\
(-3.399)\end{array}$ & $\begin{array}{l}-1.522 * * * * \\
(-3.346)\end{array}$ & $\begin{array}{l}-1.375^{* * * *} \\
(-3.525)\end{array}$ & $\begin{array}{l}-1.421 * * * \\
(-3.414)\end{array}$ & $\begin{array}{l}-1.701 * * * \\
(-3.764)\end{array}$ & $\begin{array}{l}-1.758 * * * \\
(3.679)\end{array}$ \\
\hline Democracy & $\begin{array}{l}\mathbf{0 . 1 6 1} * * * \\
(2.812)\end{array}$ & --- & $\begin{array}{l}\text { 0.188**** } \\
(3.455)\end{array}$ & --- & $\begin{array}{l}0.219 * * * \\
(7.104)\end{array}$ & --- & $\begin{array}{l}0.218 * * * \\
(3.456)\end{array}$ & --- & $\begin{array}{l}\text { 0.184**** } \\
(3.134)\end{array}$ & --- & $\begin{array}{l}\text { 0.216**** } \\
(3.138)\end{array}$ & --- \\
\hline Polity & --- & $\begin{array}{l}\text { 0.166**** } \\
(2.755)\end{array}$ & --- & $\begin{array}{l}\text { 0.194**** } \\
(3.430)\end{array}$ & --- & $\begin{array}{l}0.225 * * * \\
(6.692)\end{array}$ & --- & $\begin{array}{l}0.225 * * * \\
(3.394)\end{array}$ & --- & $\begin{array}{l}\text { 0.191**** } \\
(3.045)\end{array}$ & --- & $\begin{array}{l}\mathbf{0 . 2 2 3} * * * \\
(\mathbf{3 . 0 8 7})\end{array}$ \\
\hline Autocracy & $\begin{array}{l}0.126 \\
(1.094)\end{array}$ & $\begin{array}{l}\text { 0.301* } \\
(1.719)\end{array}$ & $\begin{array}{l}0.151 \\
(1.616)\end{array}$ & $\begin{array}{l}0.355^{* * *} \\
(2.441)\end{array}$ & $\begin{array}{l}-0.0001 \\
(-0.002)\end{array}$ & $\begin{array}{l}\text { 0.237** } \\
(\mathbf{2 . 2 7 8 )}\end{array}$ & $\begin{array}{l}0.149 \\
(0.879)\end{array}$ & $\begin{array}{l}\text { 0.388* } \\
(1.677)\end{array}$ & $\begin{array}{l}0.149 \\
(1.291)\end{array}$ & $\begin{array}{l}\text { 0.352*** } \\
(1.969)\end{array}$ & $\begin{array}{l}0.209 \\
(1.560)\end{array}$ & $\begin{array}{l}0.447 * * \\
(2.169)\end{array}$ \\
\hline Hausman test & $79.840 * * * *$ & $78.886 * * * *$ & $146.669 * * *$ & $147.026 * * *$ & $298.878 * * *$ & $298.677 * * *$ & $55.324 * * *$ & $56.080 * * * *$ & $148.124 * * *$ & $150.231 * * *$ & $145.491 * * *$ & $147.314 * * *$ \\
\hline OIR-Sargan & 5.916 & 5.796 & $11.368 * *$ & $11.109 * *$ & 1.156 & 1.285 & $9.496^{* *}$ & $8.871^{*}$ & 4.727 & 4.247 & 4.671 & 4.048 \\
\hline P-value & {$[0.205]$} & {$[0.214]$} & {$[0.022]$} & {$[0.025]$} & {$[0.885]$} & {$[0.863]$} & [0.049] & [0.064] & {$[0.316]$} & {$[0.373]$} & {$[0.322]$} & {$[0.399]$} \\
\hline Adjusted $\mathrm{R}^{2}$ & 0.170 & 0.172 & 0.193 & 0.194 & 0.597 & 0.594 & 0.284 & 0.283 & 0.186 & 0.184 & 0.208 & 0.210 \\
\hline Fisher & $7.354 * * *$ & $7.100 * * *$ & $7.842 * * *$ & $7.573 * * *$ & $77.850 * * *$ & $70.290 * * *$ & $12.278 * * *$ & $11.499 * * *$ & $8.630 * * *$ & $8.119 * * *$ & $7.481 * * *$ & $7.132 * * *$ \\
\hline \multirow[t]{3}{*}{ Observations s } & 362 & 362 & 352 & 352 & 370 & 370 & 370 & 370 & 369 & 369 & 370 & 370 \\
\hline & \multicolumn{12}{|c|}{ Panel C: Fixed Effects with HAC } \\
\hline & \multicolumn{2}{|c|}{ Control of Corruption } & Government & Effectiveness & \multicolumn{2}{|c|}{ Voice \& Accountability } & \multicolumn{2}{|c|}{ Political Stability } & \multicolumn{2}{|c|}{ Regulation Quality } & \multicolumn{2}{|c|}{ Rule of Law } \\
\hline Constant & $\begin{array}{l}-0.851 * * * \\
(-12.98)\end{array}$ & $\begin{array}{l}-\mathbf{0 . 8 6 5} * * * * \\
(-12.85)\end{array}$ & $\begin{array}{l}-0.935 * * * \\
(-14.49)\end{array}$ & $\begin{array}{l}-0.952 * * * \\
(-14.11)\end{array}$ & $\begin{array}{l}-0.912 * * * \\
(-16.70)\end{array}$ & $\begin{array}{l}-\mathbf{0 . 9 3 5 * * *} \\
(-15.80)\end{array}$ & $\begin{array}{l}-0.986 * * * \\
(-9.394)\end{array}$ & $\begin{array}{l}-1.006 * * * * \\
(-9.386)\end{array}$ & $\begin{array}{l}-0804 * * * \\
(-9.385)\end{array}$ & $\begin{array}{l}-\mathbf{0 . 8 1 7} * * * \\
\mathbf{( - 8 . 9 7 5 )}\end{array}$ & $\begin{array}{l}-0.983 * * * \\
(-13.56)\end{array}$ & $\begin{array}{l}-1.001 * * * \\
(-13.60)\end{array}$ \\
\hline Democracy & $\begin{array}{l}\mathbf{0 . 0 7 0} * * * \\
(4.098)\end{array}$ & --- & $\begin{array}{l}\mathbf{0 . 0 7 8} * * * \\
(4.558)\end{array}$ & --- & $\begin{array}{l}\mathbf{0 . 1 2 9} * * * \\
(11.05)\end{array}$ & --- & $\begin{array}{l}0.111 \text { *** } \\
(5.895)\end{array}$ & --- & $\begin{array}{l}\text { O.071*** } \\
(4.270)\end{array}$ & --- & $\begin{array}{l}\mathbf{0 . 0 8 5} * * * \\
(4.786)\end{array}$ & --- \\
\hline Polity & --- & $\begin{array}{l}0.072 * * * * \\
(4.140)\end{array}$ & --- & $\begin{array}{l}0.080 * * * \\
(4.574)\end{array}$ & --- & $\begin{array}{l}\text { 0.132**** } \\
(11.14)\end{array}$ & --- & $\begin{array}{l}0.114 * * * \\
(5.937)\end{array}$ & --- & $\begin{array}{l}0.073 * * * \\
(4.212)\end{array}$ & --- & $\begin{array}{l}0.087 * * * \\
(4.853)\end{array}$ \\
\hline Autocracy & $\begin{array}{l}-0.006 \\
(-0.343)\end{array}$ & $\begin{array}{l}\text { 0.068*** } \\
(3.590)\end{array}$ & $\begin{array}{l}-0.009 \\
(-0.638)\end{array}$ & $\begin{array}{l}0.074 * * * \\
(4.494)\end{array}$ & $\begin{array}{l}-0.062 * * * \\
(-5.330)\end{array}$ & $\begin{array}{l}0.075 * * * \\
(5.862)\end{array}$ & $\begin{array}{l}0.039 \\
(1.498)\end{array}$ & $\begin{array}{l}\text { 0.158**** } \\
(7.702)\end{array}$ & $\begin{array}{l}-0.0009 \\
(-0.052)\end{array}$ & $\begin{array}{l}\text { 0.075*** } \\
(\mathbf{3 . 0 7 0})\end{array}$ & $\begin{array}{l}0.0008 \\
(0.046)\end{array}$ & $\begin{array}{l}0.092 * * * \\
(4.728)\end{array}$ \\
\hline Adjusted $\mathrm{R}^{2}$ & 0.248 & 0.251 & 0.303 & 0.305 & 0.665 & 0.664 & 0.275 & 0.276 & 0.252 & 0.251 & 0.311 & 0.315 \\
\hline Fisher & $72.425 * * *$ & $73.807 * * *$ & $92.591 * * *$ & $93.544 * * *$ & $439.224 * * *$ & $437.161 * * *$ & $85.027 * * *$ & $85.087 * * *$ & $75.272 * * *$ & $75.089 * * *$ & $100.867 * * *$ & $102.750 * * *$ \\
\hline Observations & 434 & 434 & 422 & 422 & 442 & 442 & 442 & 442 & 441 & 441 & 442 & 442 \\
\hline
\end{tabular}

Initial Instruments $\quad$ Constant; Lower Middle Income; Middle Income; English; Christians; Free Press; Partly Free Press

Robust Instruments $\quad$ Constant; Upper Middle Income; Low Income; French; Islam; Not Free Press

*,**,***: significance levels of $10 \%, 5 \%$ and $1 \%$ respectively. OIR: Overidentifying Restrictions. 2SLS: Two-Stage-Least Squares. HAC: Heteroscedasticity and Autocorrelation Consistent. 


\subsection{Further discussion and policy implications}

We conduct our argument in this section in two strands, namely (i) closeness in the effect of democracy and autocracy and (ii) policy implications.

The first strand on closeness in the consequences has two main dimensions: difference effect and sign effect. On the one hand, concerning the difference effect, it is important to note that variations between democratic and autocratic elasticities are significant but not substantial enough to persuade autocratic regimes of the appeals of democracy in GQ. On the other hand, as regards the sign effect, elasticities of both political-regime types are positive. This is an indication that autocratic regimes are not as detrimental to improving dimensions of GQ as one might have expected.

In essence, the time and level hypotheses on the non-linear relationship between democracy and GQ could provide some insights into these closeness in outcomes. The partiality or youthfulness of African democracies renders their influences on GQ less pronounced. This is consistent with the level (Montinola and Jackman 2002; Back and Hadenius 2008; Sung 2004) and time of exposure (Keefer 2007) hypotheses.

In the second strand, a key issue in political economy is to understand how institutional arrangements shape policy outcomes. From our findings, compared to autocracy, democracy is better at stimulating GQ. However, once initiated, the democratization process should be accelerated in order to avoid the trap of the appeals of autocracy. Early democracy should be complemented with complete freedom of the press so that the benefits in GQ are substantial. Early democracy has been documented to improve income levels through higher economic growth (Shen 2002). In this light, it can be inferred from our findings that increased income levels accompanied with press-freedom policies would substantially improve democracy and GQ. As the country matures in the democratization process, it will benefit from the time and level of exposure advantages of democracy which will further improve the GQ and growth. From the underlying findings and perusal of the relevant literature, the pitfall of initiating democracy remains the failure to accelerate the process of democratization. As a policy implication, democracy, once initiated, should be hastened (to edge the appeals of authoritarian regimes) and reap the benefits of the time and level effect hypotheses. 
In line with comparative religious instruments, based on relative religious elasticities of GQ, it appears that Christian-dominated countries will have an edge over their Moslem-oriented counterparts in the implementation of proposed recommendations.

\section{Conclusions and Further Directions}

This paper has examined nexuses between law, politics and the quality of government in Africa. We have investigated whether African democracies enjoy relatively better government quality compared to their counterparts with more autocratic inclinations. The empirical evidence is based on Instrumental variable Two-Stage-Least Squares and Fixed Effects with data from 38 African countries for the period 1994-2010. Political regimes of democracy, polity and autocracy are instrumented with income levels, legal origins, religious dominations and press freedom levels to account for government, quality dynamics of corruption control, government effectiveness, voice and accountability, political-stability, regulation quality and the rule of law. The main findings indicate that democracy has an edge over autocracy while the latter and polity overlap. As a policy implication, democracy, once initiated, should be speeded up in order to edge out the appeals of authoritarian regimes and to enjoy the benefits of time and level effect outcomes.

The above findings have contributed to the literature on the sequence of institutions at various stages of development. More specifically, the debate on whether political or economic institutions should be prioritized at the early stages of industrialization remains open. Reflecting our results in the light of the time and level hypotheses for the benefits of democracy, it is to reasonable to infer that they are more closely aligned with the strand of literature advocating that economic rights should precede political rights (Kramon 2009; Anyanwu and Erhijakpor 2014). This is essentially because we have established that democratic quality increases with income levels. Future studies positioned on clarifying this inference with more macroeconomic variables would substantially improve the extant literature and enrich a recent stream of institutional literature on whether Africa's recent growth resurgence is a reality or a myth (Fosu, 2015b, Fosu, 2015c). Moreover, contingent on data availability, there are two ways in which the established linkages can be improved. First, the Fukuyama governance indicators could be adopted because they appear to be orthogonal to democratic quality advocated by the 
Washington Consensus. Second, Leonardo Morlino's framework for examining democratic quality (procedure, content and results) can also be employed. This approach has been recently employed by Nwokora and Pelizzo (2015) who have proposed an index of fluidity as a measure of party system change that captures the changeability of patterns of party competition. The proposition of the index is based on shortcomings in existing empirical approaches to capture the fact that changes in political systems may fail to reflect the extent of competition within political parties. The analytical procedure is consistent with Morlino's analytical framework of procedure, content and results.

\section{Appendices}

Appendix 1: Variable Definitions

\begin{tabular}{|c|c|c|c|}
\hline Variables & Sign & Variable Definitions & Sources \\
\hline Democracy & Demo & Institutionalized Democracy & World Bank(WDI) \\
\hline Polity & Pol & Revised Combined Polity Score & World Bank(WDI) \\
\hline Autocracy & Auto & Institutionalized Autocracy & World Bank(WDI) \\
\hline Public Investment & PubI & Gross Public Investment(\% of GDP) & World Bank(WDI) \\
\hline Population growth & Popg & Average annual population growth rate & World Bank(WDI) \\
\hline Growth of GDP & GDPg & Average annual GDP growth rate & World Bank(WDI) \\
\hline Control of Corruption & $\mathrm{CC}$ & Control of Corruption(estimate) & World Bank(WDI) \\
\hline Government Effectiveness & Gov. E & Government Effectiveness(estimate) & World Bank(WDI) \\
\hline Political Stability/ No Violence & Pols & Political Stability/ No Violence (estimate) & World Bank(WDI) \\
\hline Regulation Quality & R.Q & Regulation Quality (estimate) & World Bank(WDI) \\
\hline Rule of Law & R.L & Rule of Law(estimate) & World Bank(WDI) \\
\hline Voice and Accountability & $\mathrm{V} \& \mathrm{~A}$ & Voice and Accountability (estimate) & World Bank(WDI) \\
\hline Press Freedom & Free & Freedom House Index & Freedom House \\
\hline
\end{tabular}

WDI: World Development Indicators 
Appendix 2: Summary Statistics

\begin{tabular}{llccccc}
\hline & \multicolumn{1}{c}{ Variables } & Mean & S.D & Min. & Max. & Observations \\
& Control of Corruption & -0.622 & 0.597 & -2.489 & 1.086 & 445 \\
Government & Government Effectiveness & -0.691 & 0.598 & -1.853 & 0.807 & 433 \\
Quality & Political Stability & -0.543 & 0.922 & -3.056 & 1.108 & 454 \\
& Regulation Quality & -0.580 & 0.577 & -2.526 & 0.905 & 453 \\
& Rule of Law & -0.692 & 0.647 & -2.312 & 1.053 & 454 \\
& Voice and Accountability & -0.589 & 0.721 & -1.951 & 1.047 & 454 \\
Democracy & Democracy Index & 2.725 & 4.214 & -8.000 & 10.000 & 627 \\
& Polity Index(Revised) & 1.068 & 5.312 & -9.000 & 10.000 & 627 \\
Autocracy & Autocracy Index & 1.703 & 3.460 & -8.000 & 9.000 & 627 \\
& & & & & \\
Control & GDP growth & 4.816 & 6.725 & -50.248 & 71.188 & 644 \\
Variables & Population growth & 2.485 & 0.948 & -6.526 & 10.043 & 644 \\
& Public Investment & 7.543 & 4.200 & 0.000 & 32.032 & 564 \\
& English Common-Law & 0.394 & 0.489 & 0.000 & 1.000 & 646 \\
& French Civil-Law & 0.605 & 0.489 & 0.000 & 1.000 & 646 \\
& Christianity & 0.710 & 0.453 & 0.000 & 1.000 & 646 \\
& Islam & 0.289 & 0.453 & 0.000 & 1.000 & 646 \\
Instrumen & Low Income & 0.631 & 0.482 & 0.000 & 1.000 & 646 \\
Variables & Middle Income & 0.368 & 0.482 & 0.000 & 1.000 & 646 \\
& Lower Middle Income & 0.236 & 0.425 & 0.000 & 1.000 & 646 \\
& Upper Middle Income & 0.131 & 0.338 & 0.000 & 1.000 & 646 \\
& Press Freedom & 0.136 & 0.343 & 0.000 & 1.000 & 570 \\
& Partial Press Freedom & 0.384 & 0.486 & 0.000 & 1.000 & 570 \\
& No Press Freedom & 0.478 & 0.500 & 0.000 & 1.000 & 570
\end{tabular}

S.D: Standard Deviation. Min : Minimum. Max : Maximum. 
Appendix 3: Correlation Analysis

\begin{tabular}{|c|c|c|c|c|c|c|c|c|c|c|c|c|c|c|c|c|c|c|c|c|c|c|c|}
\hline \multicolumn{6}{|c|}{ Quality of Government } & \multicolumn{3}{|c|}{ Democracy } & \multicolumn{3}{|c|}{ Control Variables } & \multicolumn{12}{|c|}{ Instrumental Variables } \\
\hline $\mathrm{CC}$ & Gov.E & PolS & R.Q & R.L & $\mathrm{V} \& \mathrm{~A}$ & Demo & Pol & Auto & GDPg & Popg & PubI & Eng. & Frch. & Chris & Islam & LI & MI & LMI & UMI & Free & PFree & NFree & \\
\hline \multirow[t]{23}{*}{1.000} & 0.872 & 0.668 & 0.774 & 0.86 & 0.747 & 0.500 & 0.40 & -0.03 & -0.068 & -0.34 & 0.200 & 0.274 & -0.274 & 0.024 & -0.12 & -0.22 & 0.222 & -0.024 & 0.345 & 0.518 & 0.094 & -0.465 & $\mathrm{CC}$ \\
\hline & 1.000 & 0.667 & 0.851 & 0.89 & 0.796 & 0.551 & 0.45 & -0.05 & -0.006 & -0.31 & 0.178 & 0.406 & -0.406 & 0.080 & -0.16 & -0.31 & 0.310 & 0.006 & 0.422 & 0.558 & 0.116 & -0.519 & Gov. E \\
\hline & & 1.000 & 0.657 & 0.78 & 0.684 & 0.509 & 0.30 & 0.141 & 0.021 & -0.22 & 0.287 & 0.145 & -0.145 & 0.025 & -0.11 & -0.14 & 0.141 & -0.113 & 0.345 & 0.427 & 0.136 & -0.437 & PolS \\
\hline & & & 1.000 & 0.82 & 0.760 & 0.505 & 0.39 & -0.00 & -0.055 & -0.26 & 0.067 & 0.385 & -0.385 & 0.082 & -0.12 & -0.16 & 0.168 & -0.114 & 0.383 & 0.502 & 0.160 & -0.514 & R..Q \\
\hline & & & & 1.00 & 0.799 & 0.561 & 0.43 & 0.003 & -0.017 & -0.31 & 0.229 & 0.361 & -0.361 & 0.031 & -0.14 & -0.20 & 0.203 & -0.086 & 0.398 & 0.536 & 0.113 & -0.492 & R.L \\
\hline & & & & & 1.000 & 0.763 & 0.77 & -0.29 & -0.049 & -0.26 & 0.128 & 0.270 & -0.270 & -0.01 & -0.08 & -0.08 & 0.089 & -0.126 & 0.286 & 0.645 & 0.293 & -0.745 & V\&A \\
\hline & & & & & & 1.000 & 0.73 & 0.056 & 0.0341 & -0.13 & 0.241 & 0.220 & -0.220 & 0.049 & -0.04 & -0.01 & 0.018 & -0.191 & 0.257 & 0.477 & 0.226 & -0.543 & Demo \\
\hline & & & & & & & 1.00 & -0.63 & -0.069 & -0.15 & 0.182 & 0.147 & -0.147 & 0.105 & -0.10 & 0.051 & -0.051 & -0.224 & 0.198 & 0.487 & 0.259 & -0.582 & Polity \\
\hline & & & & & & & & 1.00 & 0.149 & 0.070 & 0.019 & 0.043 & -0.043 & -0.09 & 0.098 & -0.09 & 0.096 & 0.109 & 0.003 & -0.16 & -0.11 & 0.222 & Auto \\
\hline & & & & & & & & & 1.000 & 0.264 & 0.110 & -0.03 & 0.035 & 0.011 & -0.02 & -0.08 & 0.088 & -0.011 & 0.139 & 0.018 & -0.05 & 0.036 & GDPg \\
\hline & & & & & & & & & & 1.000 & -0.04 & -0.21 & 0.211 & -0.10 & 0.153 & 0.322 & -0.322 & -0.178 & -0.23 & -0.24 & 0.063 & 0.107 & Popg \\
\hline & & & & & & & & & & & 1.000 & -0.05 & 0.057 & -0.08 & -0.02 & -0.01 & 0.012 & 0.020 & -0.00 & 0.043 & 0.188 & -0.212 & PubI \\
\hline & & & & & & & & & & & & 1.000 & -1.000 & 0.085 & -0.04 & -0.16 & 0.164 & 0.056 & 0.163 & 0.190 & 0.041 & -0.170 & English \\
\hline & & & & & & & & & & & & & 1.000 & -0.08 & 0.040 & 0.164 & -0.164 & -0.056 & -0.16 & -0.19 & -0.04 & 0.170 & French \\
\hline & & & & & & & & & & & & & & 1.000 & -0.93 & -0.04 & 0.049 & -0.154 & 0.264 & 0.07 & -0.10 & 0.054 & Christian \\
\hline & & & & & & & & & & & & & & & 1.000 & 0.126 & -0.126 & 0.053 & -0.24 & -0.09 & 0.068 & -0.000 & Islam \\
\hline & & & & & & & & & & & & & & & & 1.000 & -1.000 & -0.729 & -0.50 & -0.17 & 0.109 & 0.011 & LIncome \\
\hline & & & & & & & & & & & & & & & & & 1.000 & 0.729 & 0.50 & 0.17 & -0.10 & -0.011 & MIncome \\
\hline & & & & & & & & & & & & & & & & & & 1.000 & -0.21 & -0.17 & 0.001 & 0.118 & LMI \\
\hline & & & & & & & & & & & & & & & & & & & 1.000 & 0.464 & -0.15 & -0.165 & UMI \\
\hline & & & & & & & & & & & & & & & & & & & & 1.000 & -0.31 & -0.381 & Free \\
\hline & & & & & & & & & & & & & & & & & & & & & 1.000 & -0.757 & PFree \\
\hline & & & & & & & & & & & & & & & & & & & & & & 1.000 & NFree \\
\hline
\end{tabular}

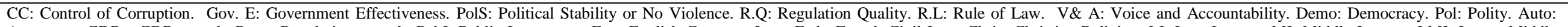

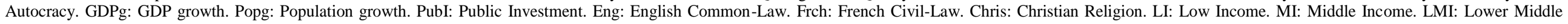
Income. UMI: Upper Middle Income. Free: Freedom of the Press. PFree: Partial Freedom of the Press. NFree: No Freedom of the Press. 


\section{Appendix 4: Presentation of Countries}

\begin{tabular}{|c|c|c|c|}
\hline Instruments & Instrument Category & Countries & Num. \\
\hline \multirow[t]{2}{*}{ Legal-origins } & English Common-Law & $\begin{array}{l}\text { Botswana, The Gambia, Ghana, Kenya, Lesotho, Malawi, } \\
\text { Mauritius, Nigeria, Sierra Leone, South Africa, Sudan, } \\
\text { Swaziland, Uganda, Zambia, Tanzania. }\end{array}$ & 15 \\
\hline & French Civil-Law & $\begin{array}{l}\text { Angola, Benin, Burkina Faso, Burundi, Cameroon, Cape Verde, } \\
\text { Central African Republic, Chad, Congo Republic, Congo } \\
\text { Democratic Republic, Ivory Coast, Equatorial Guinea, Ethiopia, } \\
\text { Gabon, Guinea-Bissau, Madagascar, Mali, Mauritania, } \\
\text { Mozambique, Niger, Rwanda, Senegal, Togo. }\end{array}$ & 23 \\
\hline Religions & Christianity & $\begin{array}{l}\text { Angola, Benin ,Botswana, Burundi, Cameroon, Cape Verde, } \\
\text { Central African Republic, Congo Republic, Congo Democratic } \\
\text { Republic, Ivory Coast, Equatorial Guinea, Ethiopia, Gabon, } \\
\text { Ghana, Kenya, Lesotho, Madagascar, Malawi, Mauritius, } \\
\text { Mozambique, Rwanda, South Africa, Swaziland, Togo, Uganda, } \\
\text { Zambia, Tanzania. }\end{array}$ & 27 \\
\hline \multirow{5}{*}{ Income Levels } & Islam & $\begin{array}{l}\text { Burkina Faso, Chad, The Gambia, Guinea-Bissau, Mali, } \\
\text { Mauritania, Niger, Nigeria, Senegal, Sierra Leone, Sudan. }\end{array}$ & 11 \\
\hline & Low Income & $\begin{array}{l}\text { Benin ,Burkina Faso, Burundi, Central African Republic, Chad, } \\
\text { Congo Republic, Congo Democratic Republic, Ethiopia, The } \\
\text { Gambia, Ghana, Guinea-Bissau, Kenya, Madagascar, Malawi, } \\
\text { Mali, Mauritania, Mozambique, Niger, Rwanda, Sierra Leone, } \\
\text { Togo, Uganda, Zambia, Tanzania. }\end{array}$ & 24 \\
\hline & Middle Income & $\begin{array}{l}\text { Angola ,Botswana, Cameroon, Cape Verde, Ivory Coast, } \\
\text { Equatorial Guinea, Gabon, Lesotho, Mauritius, Nigeria, Senegal, } \\
\text { South Africa, Sudan, Swaziland. }\end{array}$ & 14 \\
\hline & Lower Middle Income & $\begin{array}{l}\text { Angola, Cameroon, Cape Verde, Ivory Coast, Lesotho, Nigeria, } \\
\text { Sudan, Swaziland. }\end{array}$ & 8 \\
\hline & Upper Middle Income & Botswana, Equatorial Guinea, Gabon, Mauritius, South Africa. & 5 \\
\hline
\end{tabular}

Num: Number of cross sections(countries) 


\section{References}

Agbor, Julius. 2015. How does colonial origin matter for economic performance in SubSaharan Africa?, in Growth and Institutions in African Development, First edited by Augustin K. Fosu, 2015, Chapter 13, pp. 309-327, Routledge Studies in Development Economics: New York.

Asongu, Simplice. 2012. "Government Quality Determinants of Stock Market Performance in African Countries" Journal of African Business 13(3): 183-199.

Asongu, Simplice. 2014a. "Globalization (fighting) corruption and development: how are these phenomena linearly and nonlinearly related in wealth effects" Journal of Economic Studies 41(3): 346-369.

Asongu, Simplice. 2014b. "The questionable economics of development assistance in Africa: hotfresh evidence, hot-fresh evidence" The Review of Black Political Economy 41(4): 455- 480.

Asongu, Simplice. 2015. "On Taxation, Political Accountability and Foreign Aid: Empirics to a Celebrated Literature" South African Journal of Economics 83(2): 180-198.

Asongu, Simplice. 2016a. "Sino-African relations: a review and reconciliation of dominant schools of thought" Politics \& Policy, 44(2): 351-383.

Asongu, Simplice. 2016b. "Determinant of Growth in Fast Developing Countries: Evidence from Bundling and Unbundling Institutions" Politics \& Policy 44(1): 97-134.

Asongu, Simplice, and Nwachukwu, Jacinta. 2015. "Revolution Empirics: Predicting the Arab", Empirical Economics, http://link.springer.com/article/10.1007\%2Fs00181-015-1013-0

Asongu, Simplice, and Ssozi, John. 2016. "Sino-African Relations: Some Solutions and Strategies to the Policy Syndromes" Journal of African Business 17(1): 35-51.

Armijo, Leslie. 1999. Financial Globalization and Democracy in Emerging Markets. New York: Palgrave Macmillan.

Back, Hanna, and Hadenius, Axel. 2008. "Democracy and State Capacity: Exploring a J-Shaped Relationship" Governance 21(1): 1-24.

Lake, David, and Baum, Mathew. 2001. "The Invisible Hand of Democracy: Political Control and the Provision of Public Services" Comparative Political Studies 34(6): 587-621.

Baum, Mathew, and Lake, David. 2003. "The Political Economy of Growth: democracy and human capital" American Journal of Political Science 47(2): 333-347.

Beck, Thorsten, Demirgüç-Kunt, Asli. and Levine, Ross. 2003. "Law and finance: why does legal origin matter?" Journal of Comparative Economics 31(4): 653-675. 
Beal, Amanda, and Graham, Leah. 2014. "Foundations for Change: Rule of Law, Development, and Democratization" Politics \& Policy 42(3): 311-345.

Bhagwati, Jagdish. 1995. "Democracy and Development: new thinking on an old question" Indian Economic Review 30(1): 1-18.

Blanchard, Olivier, and Shleifer, Andrei. 2001. "Federalism with and without political centralization; China versus Russia" IMF Staff Papers 48(1): 171-179.

Charron, Nicholas, and Lapuente, Victor. 2009. "Does Democracy Produce Quality of Government?" European Journal of Political Research 49(4): 443-470.

Clague, Christopher, Keefer, Philip, Knack, Stephen, and Olson, Mancur. 1996. "Property and Contract Rights in Autocracies and Democracies" Journal of Economic Growth 1(2): 243-276.

Denizer, Cevdet, Kaufmann, Daniel, Kraay, Aart, 2013. "Good countries or good projects? Macro and micro correlates of World Bank project performance" Journal of Development Economics 105(2013): 288-302.

Diamond, Larry. 2007. "A quarter-century of promoting democracy" Journal of Democracy 18(4):118-120.

Dixit, Avinash. 2009. "Governance Institutions and Economic Activity" American Economic Review 99(1):5-24.

Doucouliagos, Hristos, and Ulubasoglu, Mehmet. 2008. "Democracy and Economic Growth: A Meta-Analysis" American Journal of Political Science 52(1): 61-83.

El Badawi, Ibrahim, and Makdisi, Samir. 2007. "Explaining the democracy deficit in the Arab world" The Quarterly Review of Economics and Finance 46(5): 813-831.

Fails, Mathew. 2014. "Leader Turnover, Volatility, and Political Risk" Politics \& Policy 42(3): 369-399.

Fonchingong, Charles. 2014. "Firming Up Institutional Policy for Deprived Elderly in Cameroon" Politics \& Policy 42(6): 948-980.

Fosu, Augustin. 2008. "Inequality and the growth-poverty nexus: specification empirics using Africa data" Economics Letters 100(3): 442-444.

Fosu, Augustin. 2013. "Growth of African Economies: Productivity, Policy Syndromes and the Importance of Institutions" Journal of African Economies 22(4): 523-551.

Fosu, Augustin. 2015a. "Growth, Inequality and Poverty in Sub-Saharan Africa: Recent Progressin a Global Context" Oxford Development Studies, 43(1): 44-59. 
Fosu, Augustin. 2015b. Growth and Institutions in African Development, First edited by Augustin K. Fosu, , Routledge Studies in Development Economics: New York

Fosu, Augustin. 2015c. Growth and institutions in African Development, in Growth and Institutions in African Development, First edited by Augustin K. Fosu, 2015, Chapter 1, pp. 117, Routledge Studies in Development Economics: New York.

Fukuyama, Francis. 2013. “What is Governance?”, Governance, 26(3): 347-368.

Glen, Carol. (2014). “Internet Governance: Territorializing Cyberspace?” Politics \& Policy42(5): 635-657.

Haggard, Stephan. 1997. Democratic Institutions and Economic Policy, in Christopher Clague (ed.), Institutions and Economic Development. Baltimore: Johns Hopkins University Press.

Harris-White, Barbara. 1996. Liberalization and New Forms of Corruption. Brighton: Institute of Development Studies.

IMF 2005. "The IMF Approach to Promoting Good Governance and Combating Corruption-A Guide" International Monetary Fund.

http://liblists.sussex.ac.uk/items/92267647-5B32-673B-4064-208706C0B30E.html （Accessed: 05/07/2015)/

Ikeanyibe, Okechukwu. 2014. "Internal Party Democracy, Party Candidature, and Democratic Consolidation in Nigeria's Fourth Republic" Politics \& Policy 42(5): 769-804.

Jakubow, Alexander. 2014. "State Intervention and Life Satisfaction Reconsidered: The Role of Governance Quality and Resource Misallocation" Politics \& Policy 42(1): 3-36.

Kaufmann, Daniel, Kraay, Aart, and Mastruzzi, Massimo. 2007a. "Growth and Governance: A Reply" Journal of Politics 69(2): 555-562.

Kaufmann, Daniel, Kraay, Aart, and Mastruzzi, Massimo. 2007b. "Growth and Governance: A Rejoinder" Journal of Politics 69(2): 570-572.

Kaufmann, Daniel, Kraay, Aart, and Mastruzzi, Massimo. 2010. "The worldwide governance indicators: Methodology and analytical Issues". World Bank Policy Research Working Paper No 5430, Washington.

Keefer, Philip. 2007. "Clientelism, Credibility, and the Policy Choices of Young Democracies" American Journal of Political Science 51 (4): 804-821.

Kim, Dukhong. 2014. "The Effect of Partisanship, Sophistication, and Political Contexts on Belief in Democracy Promotion" Politics \& Policy 42(5): 658-692. 
Kramon, Eric. 2009. "Vote Buying and Turnout in Kenya's 2002 Elections", University of California, Los Angeles, http://www.sscnet.ucla.edu/polisci/wgape/papers/17_Kramon.pdf (Accessed: 23/08/2015).

Kurtz, Marcus, and Schrank, Andrew. 2007a. "Growth and Governance: Models, Measures, and Mechanisms" Journal of Politics 69(2): 538-554.

Kurtz, Marcus, and Schrank, Andrew.2007b. "Growth and Governance: A Defense", Journal of Politics, 69(2), pp. 563-569.

La Porta, Rapheal., Lopez-de-Silanes, Florencio., Shleifer, Andrei., and Vishny, Robert. 1997. "Legal Determinants of External Finance" Journal of Finance, 52(July): 1131-1150.

La Porta, Rapheal., Lopez-de-Silanes, Florencio., Shleifer, Andrei., and Vishny, Robert. 1998. "Law and finance” Journal of Political Economy 106(6): 1113-1155.

Lalountas, Dionisios, Manolas, George, and Vavouras, Ioannis. 2011. "Corruption, globalization and development: How are these three phenomena related?"Journal of Policy Modeling, 33(4): 636-648.

Lemarchand, Rene. 1972. "Political Clientelism and Ethnicity in Tropical Africa: Competing Solidarities in Nation-Building" American Political Science Review 66(1): 68-85.

Montinola, Gabriellar. R. and Jackman, Robert. 2002. "Sources of Corruption: A CrossCountry Study" British Journal of Political Science 32(1): 147-170.

Moyo, Dambisa. 2013. "Is China a new idol for developing countries", TED Talks, New Ideas Every day, https://www.youtube.com/watch?v=4Q2aznfmcYU (Accessed: 07/05/2014).

Mulligan, Casey, Gil, Richard and Sala-i-Martin, Xavier. 2004. "Do democracies have different public policies that on nondemocracries" Journal of Economic Perspectives 18(1): 51-74.

Narayan, Paresh, Narayan, Seema, \& Smyth, Russell. 2011. "Does democracy facilitate economic growth or does economic growth facilitate democracy? An empirical study of SubSaharan Africa" Economic Modelling 28(3): 900-910.

North, Douglass. 1990. Institutions, Institutional Change and Economic Performance, Cambridge University Press.

Nwokora, Zim, and Pelizzo, Riccardo. 2015. "The Political Consequences of Party System Change" Politics \& Policy 43(4): 453-473.

Olson, Mancur. 1982. The rise and decline of nations. New Haven: Yale University Press.

Oscarsson, Henrik. 2008. "Media and Quality of Government: A research overview", Quality of Government Working Paper Series, 2008/12, Gothenburg. 
Rao, Vaman. 1984. "Democracy and economic development" Studies on Competitive International Development 19(4): 67-81.

Rodrik, Daniel. 2000. "Institutions for High-Quality Growth: what they are and how to acquire them" Studies in International Comparative Development 35(3): 3-31.

Rothstein, Bo. 2011. "Quality of government and epistemic democracy", Quality of Government Institute, University of Gothenburg.

Sayari, Sabri. 1977. Political Patronage in Turkey, in E. Gellner and J. Waterbury (eds.), Patons and Clients in Mediterranean Societies, London: Duckworth, pp. 103-113.

Scott, James. 1972. Comparative Political Corruption, Englewood Cliffs, NJ: Prentice-Hall.

Shen, Jian-Guang. 2002. "Democracy and growth: An alternative empirical approach", Bank of Finland, Institute for Economies in Transition, BOFIT Discussion Papers 13/2002, Helsinki.

Stulz, Rene, and Williamson, Rohan. 2003. "Culture, Openness and Finance" Journal of Financial Economics 70(3): 313-349.

Sung, H-E. 2004. "Democracy and political corruption: a cross-national comparison" Crime, Law and Social Change 41(2):179-194.

Tusalem, Rollin. 2015, "State Regulation of Religion and the Quality of Governance" Politics \& Policy 43(1): 94-141.

VanDusky-Allen, Julie. 2014. "The Conditional Effect of Term Limits on Electoral Activities" Politics \& Policy 42(3): 431-458.

Vaidya, Samarth. 2005. "Corruption in the media's gaze" European Journal of Political Economy, 21(3): 667-687.

Varese, Federico. 1997. "The Transition to the Market and Corruption in Post-socialist Russia" Political Studies 45(3): 579-96.

Wade, Robert. 1985. "The Market for Public Office: Why the Indian State is not better at Development" World Development 13(4): 467-97.

Waheduzzaman, Wahed. and As-Saber, Sharif. 2015. "Politics and Policy in Achieving Participatory Governance in a Developing Country Context" Politics \& Policy 43(4): 474-501.

Weyland, Kurt. 1998. "The Politics of Corruption in Latin America" Journal of Democracy 9 (2):108-121. 
World Bank 2015. "World Development Indicators', World Bank Publications http://www.gopa.de/fr/news/world-bank-release-world-development-indicators-2015 (Accessed: 25/04/2015).

Yang, Benhua. 2011. "Does democracy foster financial development? An empirical analysis" Economic Letters 112(3): 262-265. 